\title{
特集 「ビッグイベントと不動産経済」【論説】
}

\section{オリンピックがもたらす不動産市場への影響}

Impact on Real Estate Markets by Olympic Games

Yoshio NAKAYAMA : XYMAX Real Estate Institute Corporation Director

This article explains about how Olympic Games give impact on real estate markets. Especially it focuses on upcoming Year 2020 Tokyo Game. Firstly it analyzes the meaning of Olympic Games as big events, and briefly introduces Year 2020 Tokyo one. Then, it discusses how Olympic impact on macro economy and which industries are affected. As the level of impact is different by property type, the article analyses the impact by property type (i.e., residential, office, retail, hotel, industrial and so on). Olympic will be the important trigger to facilitate urban renewal and rehabilitation of the city.

\section{1. はじめに}

2013年 9 月に2020年夏季五輪の開催都市を決め る国際オリンピック委員会（IOC）総会がブエノ スアイレスで開かれ，東京が選ばれた。1964年以 来56年ぶりで, 2 回目の開催はアジアでは初めて である。今回の本誌特集は,「ビッグイベントと 不動産経済」である。ビッグイベントとは, 大規 模な催し物や重大な出来事のことであるが，オリ ンピック・パラリンピック（以下，“オリンピッ ク”または“五輪”という）は，数あるイベントの 中でもその規模や知名度の点で, 最大級のもので あると言えよう。

東京でのオリンピック開催決定後, いくつかの 研究機関が, その経済効果がどの程度であるかの 予測をしている1。しかし, その数值にはかなり の幅があり，それぞれが前提としている経済効果
等が異なっていることも相俟って， 6 年後の将来 を予測することの難しさを示している。

また，過去のオリンピック開催地をケーススタ ディとして分析することは, 学問的には意義深い ことであり, 別稿で考察されている。しかし, 開 催国・都市の状況も区々であり，同一都市である 東京でさえ，1964年当時と現在の経済環境や都市 整備の状況も大きく異なっているため, それらを 2020年の東京の予測にそのまま当てはめることは できない。

したがって，本稿では，2020年夏季五輪の経済 効果を計量的に予測したり, あるいは, 過去の才 リンピック開催地との比較を行うのではなく, オ リンピックというビッグイベントがマクロ経済や 不動産マーケットにどのような影響を及ぼすかと いう，メカニズムの解明を主目的とする。

中山 善夫* (なかやま よしお) 正会員・(株) ザイマックス不動産総合研究所 取締役

1 東京2020オリンピック招致委員会は, 五輪開催の経済効果を 3 兆円（注： 3 兆円は現在のGDPの約 $0.6 \%$ ), 15 万人の雇 用創出と予測。一方, 森記念財団の都市戦略研究所は, 19.4 兆円の経済波及効果, 全国で 121 万人 (年平均で 17 万人) の 雇用を生むと試算。また, みずほ総合研究所は, 直接効果は約 1 兆円, 生産誘発総額は約 2.5 兆円, 21 万の雇用創出と 試算。さらに大和証券では150兆円以上の経済効果と予測。 


\section{2. 夏季オリンピック・パラリンピックの 位置づけ}

夏季オリンピックは, 近代オリンピックのうち 夏季に行われるもので, 4 年に 1 度, 開催される。 1896年の第 1 回アテネ大会から数えて, 第32回の 東京大会は, 2020年 7 月 24 日〜 8 月 9 日の 17 日間 で，28競技が開催される予定である。一方，パラ リンピックは, 主に肢体不自由の身体障害者（視 覚障害を含む）を対象とし，2020年 8 月25日〜 9 月 6 日の 13 日間に 22 競技が開催される。

夏季オリンピック・パラリンピックは, 合計わ ずか30日間のイベントであるものの, ビッグイベ ントとして注目を集める理由としては, (1)世界最 古で最大級のスポーツイベントであること, (2)最 高峰の競技が行われること, (3)世界200力国以上 から一流選手が一同に集まること, (4)世界220以 上の国・地域でTV放映されること（ちなみにロ ンドン大会の開会式は 10 億人, 北京大会は 8 億人 が視聴したと言われる), (5)オリン゚ック開催の ために, 施設建設, インフラ整備等, 多額の投資 が行われることなどが挙げられる。

\section{2020年東京大会の特徵}

大会の詳細については, 別稿に譲るが, 特徵を 一言で表現すれば, “都市の中心で開催するコン パクトな大会”である。具体的には, (1) 選手村を 都市の中心に配置し, 最短の移動時間が可能な会 場配置，(2) $85 \%$ の競技会場とすべてのIOCホテル は選手村から $8 \mathrm{~km}$ 圈内に配置, (3)1964年大会の レガシーを語り継ぐヘリテージゾーンに新しい五 輪スタジアムを新設, (4)未来に向けて発展する東 京の姿を象徵する東京ベイゾーン（臨海地区）に は 9 つの恒久競技会場を新設することなどであり, 2012年のロンドン大会と同様, 成熟都市での開催 となる。

1964年当時の日本は, 高度経済成長の真っただ 中にあり, 前回のオリンピックは, 当時, 貧弱 だった都市交通や生活環境などの多くの問題を
抱えていた東京を一挙に改造する千載一遇のチャ ンスとなった。当時のGDPは30兆円弱で, 現在 の約 16 分の 1 , 一般会計歳入額が 3.4 兆円に対し, 約 1 兆円（大会運営及び競技場建設等の直接経 費 : 約265億円, 街路, 上下水道, 新幹線等の間 接経費：約9,600億円）の支出を行った。

今回の費用について, 東京都の『TOKYO 2020立候補ファイル』によれば，直接的な予算と して3,400億円, 加えて, 競技会場や選手村の建 設, 東京都内にあるスポーツ施設の改修, セキュ リティ, 通信インフラ, 医療施設の整備など, 大 会に隣接する予算も含めると, 約 8,000 億円が必 要になる見通しである。

現在の日本は, 既に先進国の仲間入りを果たし, 経済大国となっている。バブル崩壊後, デフレが 続き，アベノミクスにより，デフレ脱却を試みて いる状況である。高度経済成長期やバブル期に作 られたインフラ施設や中小オフィスビルの老朽化 も進んでいる。日本全国的には, 人口の減少が予 測されているが，東京などの一部の大都市につい ては，当面は引き続き人口流入が続くと予測され ている。東京都は2013年 1 月に「『2020年の東京』 へのアクションプログラム2013」を発表した。そ の内容は, オリンピック開催時における東京の都 市像を示したものであるが,「高度な防災都市を 実現し, 東京の安全性を世界に示す」,「産業力と 都市の魅力を高め, 東京を新たな成長軌道に乗せ る」等の 8 つ目標を掲げている。

\section{4 、マクロ経済に与える影響}

ここでは，オリンピックというビッグイベント が, 日本経済や開催地である東京の地域経済にど のように影響を与えるかについて考察する。第一 に, 大会開催の直接的な効果として, 期間中の チケット売上, 放送・広告売上, 国内外からの来 訪者の滞在費及び飲食費などがある。また，競技 施設や選手の宿泊施設, プレスセンターなどの新 規建設もある。第二に, 間接的な効果として, 大 会に向けた諸々のインフラの整備・更新等が考え 
られる。東京の都市インフラも長年が経過し, 老 朽化しており，オリンピックに向けて，これらの 更新のスピードが上がる可能性が大きい。さら に，第三に，派生的な効果として，国民や国民経 済に対するポジテイブ効果がある。これは，オリ ンピック開催という明るい話題を提供することで, ムードメーカーとなって, 人々の期待や夢を誘い, 経済を活気づける効果である。

なお, 海外の研究であるが, オリンピックの開 催経験が, 輸出を少なくとも $20 \%$ 長期的に増やす 効果があるとの研究もある2。輸出が増える理由 としては, オリンピック招致への立候補は, 政府 がこれから貿易の自由化を本気で行う意図を企業 や投資家に信じてもらえるシグナルとしての機能 であるとする。

\section{5. オリンピックにより影響を受ける業種}

どのような業種がオリンピック開催により大き な影響を受けるのであろうか。まずは，オリン ピック関連施設の建設やインフラ工事の促進によ り建設業界が挙げられる。また，大会中のみな らず，その前後も含めた滞在者や旅行者の増加に よりホテル業界，観光業界も影響を受ける。また， 大会運営面では, 報道・マスコミ業界, 広告・宣 伝業界や警備業界も影響があるであろう。さらに, 航空業界，鉄道業界や，オリンピック関連商品の 販売, 観光客等による飲食店やサービス・小売業 などが需要拡大し，幅広い業種でプラスの影響を 受けるものと考えられる。

商工リサーチが実施した経営者アンケートによ れば，オリンピックの業界への影響につき，回答 者の $60 \%$ 以上が良い影響を期待し，好感をもって 受け止めている。業界別では, 金融・保険業が高 く, 建設業では, 建設資材の高騰や職人の人件費 アップなどが収益の圧迫材料として懸念されてい るなか, 今後のオリンピック関連需要でいっそう
加速されるのではないか, と冷静に受け止めてい る。自社の所在する都道府県への影響については, 「良い影響」とする回答が東京では 9 割を占めて いる ${ }^{3}$ 。

なお，北京オリンピックに関する研究で，オリ ンピックの開催により, 好景気を得る業界は主に 投資および消費サービスであり，オリンピックは， 観光, 小売業, 不動産, 建築, 交通, スポーツ, 情報, 通信などの 8 大産業分野に大きな影響を及 ぼすものと紹介している4。

\section{6．不動産市場への影響}

次にオリンピックというビッグイベントが不動 産市場にどのような影響を与えるのかを考察する。 不動産市場は, 一般的に, スペースマーケットと 不動産キャピタルマーケットの 2 つに区分される が, 前者は不動産の賃貸市場で, 後者が取引市場 である。賃貸市場の対象は, “床（スペース）”で あり, 供給側は建物所有者, 需要者側はテナント である。賃貸市場では, 床の需要は, 実需である ので, 経済やテナントの業績が改善すれば, 床需 要の増大となる。最近では, このようなプラスの 動きが既に始まっている。一方, 後者の不動産の 取引市場は，もっぱら不動産投資家の投資意欲の 強さにより影響する。現にアベノミクス直後から 認められる動きとしては, インフレ期待, 不動産 市況の底打ち感, 円安による海外投資家の増加な どにより，不動産を購入したい希望者が急増して いるが，売り物件の数が相対的に限定されている ことから, 競争が激化し, キャップレートも低下 傾向にある。また，不動産をテナントとして借り ていた企業が，余剰資金やインフレ予測などから， “借りる (賃借)”から“持つ (所有)”方向に不動産 戦略の舵を切り替える企業も増えつつある。不動 産といっても，色々な使われ方をしていて，それ ぞれ特徴があるので，以下では，用途別に説明し 
ていきたい。

\section{（1）住宅}

2020年東京オリンピックの開催決定により, 脚 光を浴びているのが，東京べイゾーンである。も ともと新しいエリアで, マンションなどの大型開 発が行われていたが，大会のメインエリアになる ことがアナウンスされ，恒久競技施設などが新設 され，鉄道や道路などの輸送網のインフラもさら に整備される計画がある。マンション購入のニー ズは，自用か賃貸用（投資用）のいずれかになる が，期待が先行し，既に価格が上昇し始めている。 2020年に向けて，この傾向は続くであろう。

それでは, 東京ベイゾーン以外ではどうか。近 接するエリアや神宮などでは, オリンピック人気 のご利益を受けるところもあると思うが，東京 23 区のその他のエリアでは，オリンピックによる影 響は極めて限定的であると考えられる。その理由 としては，住宅は“人が住む”場所であり，その快 適性や利便性に影響を与える要因が, 価格や賃料 を形成する要因となる。オリンピックは，あくま でも合計30日間のイベントであり，そのこと自体 が，東京の幅広い住宅エリアに影響を及ぼすとは 考えにくい。仮に，オリンピックを契機に海外か ら日本に住みたいというニーズが急激に高まれば, オリンピックのプラス効果と考えられる。現実的 には恒久施設やインフラ整備による利便性の向上 とオリンピック開催エリア内と言ったアピールポ イントが, 不動産価格や貨料に一定期間，影響を 及ぼすであろう。

\section{(2) オフィス}

オフィスは, 企業活動の“場”であり, 人（＝才 フィスワーカー）が働く場所である。オフィスを 使う企業やオフィスワーカーの増加がオフィスの “床”需要の源泉となる。オリンピックを契機にこ れらが増加し, オフィスの床需要が増大すれば,
影響を受けたと考えられる。しかし，前述のとお り，オリンピックは，ビッグイベントではあるも のの短期間であり，オフィスの賃貸借の意思決定 は中長期のコミットメント（例：通常の賃貸借契 約自体は 2 年間であるが，平均的な入居期間は約 10年 $\left.{ }^{5}\right)$ であることから，それ自体からのオフィ 久需要の創造効果は極めて限定的であると思われ る。むしろ，デフレ脱却から持続的な経済成長に 向かうことで, ファンダメンタルズが回復し, 企 業業績が向上すれば，オフィス需要へつながって いくであろう。

また，オリンピックの中心開催エリアである東 京ベイゾーンには, オフィスビルもあるものの, 東京のメインのオフィスエリアではなく，オリン ピックを契機にオフィスエリアとしてのポテン シャルが急に上がるとは考えにくい。但し，オリ ンピックに向けた交通などのインフラ整備が, 東 京ベイゾーンのオフィスにプラスの影響を及ぼす ことは考えられる。

なお，政府は，アべノミクスの第 3 の矢，成長 戦略の 1 つとして, 国家戦略特区の指定を盛り込 んでおり，東京都もそのうちの 1 つに指定された。 具体的な内容はこれからであるが，そのうちの 1 つに外資系企業の誘致がある。オリンピック開催 決定は, 明るい材料であるが, 世界の都市間競争 に勝つために, 今後の税制優遇での企業誘致や東 京の拠点性と都市機能を強化する投資が鍵を握る であろう。

\section{(3) 商業施設}

商業施設は, 物品の販売やサービスの提供, 飲 食を行うための不動産であり，その賃料や価格は， もっぱら売上などの収益性を基に決定され，テナ ントは，そこでの売上から賃料を支払っている。

オリンピック開催期間中及びその前後は, 国 内外から大勢の人 ${ }^{6}$ が東京に来て，オリンピック 関連商品やお土産品を購入，飲食したりするの 
で，これらに関連する小売業，サービス業や飲食 業の売上は直接的に影響があるであろう。国内消 費においても，プラスの影響が考えられる。例え ば，オリンピックを契機に家電（例：テレビ）等 の購入, スポーツ活動の拡大, スポーツ用品の購 入，国際交流への自己投資の拡大が考えられる。

また，オリンピックにより，東京が全世界に紹 介されることとなるので, 観光客の増加も期待で き, これに伴う店舗売上の増加も期待できるであ ろう。

\section{(4) ホテル}

ホテルは，オリンピックの直接的な影響を最も 受ける業種の 1 つである。国内外からの来訪者は, どこかに宿泊滞在する必要があり, 大会期間中は 選手，報道，応援者など，特に大勢が集まるので， 極めて高いホテル稼働率となり, 客室も特別料金 となる可能性が高い。併せて, 海外からの観光客 の増加は，ホテル業界にとっては追い風となるで あろう7。

過去のオリンピック開催国では, 多くのケース で, オリンピック開催決定後に海外からの旅行 者が長期的に増加する傾向があり ${ }^{8}, こ の$ 傾向は, 主催都市以外でも観光客が増加しているケースも あるという。また，ジョーンズ・ラング・ラサー ル社の調べでは, 北京とロンドンでは, オリン ピック開催決定から開催までの 7 年間のRevPER (Revenue per Available Room, 販売可能客室 1 室あたり売上）上昇率は 12 年間の平均よりも高 かったとしている ${ }^{9}$ 。のように明るい見通しか ら，不動産投資としても，ホテルは注目を集めて いるセクターである。なお, 今後, ホテルの新規 開業による多少の増加も見込まれるものの, IOC 委員会は, 東京都心から半径50キロメートル内に
既に国際基準を満たす客室数約14万室のホテル， 9,500室の旅館が存在すると報告している。

政府は，海外からの観光客の増加を目論んでお り，2030年までに3,000万人にしょうとしている (参考：2013年実績は 1,036 万人)。なお，ビジッ ト・ジャパン・キャンペーンが開始した2003年は 521 万人で，その後 10 年間で倍増した。その背景 には，円安の進行，アジア諸国等へのビザ発給 要件の緩和, 首都圈空港の発着枠数の増加などが ある。今後の観光客の増加を占う上で重要な役割 を果たしているのが空港である。東京の空の立関, 羽田空港が国際化に向けて大幅に増便し, 国際線 の年間発着枠は2013年度末に今までの 6 万回から 9 万回になった。今後の観光客増大のためには, さらなる増便のための滑走路の増設が望まれる。

\section{（5）物流施設}

物流施設は, 物品の配送や保管の拠点である。 インターネットの普及により, eコマースが普及・ 拡大してきており，現実の店舗の売上を席巻して きており，今後ともこの傾向は続くものと考えら れる。オリンピックとのつながりで考えると, オ リンピック関連商品の配送・保管に関わるニー ズが特需と考えられるが，オリンピック自体が一 定期間の開催であり，この特需自体が，物流施設 の価格や賃料に影響するほど大きいものではない であろう。むしろ，オリンピックに関連したイン フラ整備（道路など）が前倒しで行われることで, 輸送時間の短縮という点で収益性に貢献すること はあるであろう。

\section{（6）観光地・レジャー施設}

オリンピックのために来日した外国人は, 東京 都内及び国内の観光地やレジャー施設も併せて訪

\footnotetext{
6 政府は, オリンピック開催中，850万人の観光客が訪れると試算

7 日経リサーチの調查によれば, 全国のホテル・旅館の 5 割が東京五輪に期待していると回答している（2014年 2 月 20 日 日本経済新聞)

8 参考文献No. 1 参照

9 参考文献No. 4 参照
} 
れるであろう。また，オリンピックにより，東京 及び日本がPRされることとなるので, 大会終了 後も外国人観光客が引き続き増加することが予測 される。そうなると, 観光地やレジャー施設の収 益性が継続的に向上し，価格や賃料に影響を及ぼ す可能性がある。

\section{（7）不動産取引市場}

上記(1)〜(6)では，もっぱらスペースマーケッ 卜（賃貸市場）の主だった用途について，オリン ピックの影響を考察した。

不動産キャピタルマーケット（不動産取引市 場）での買主の着眼点は, 一般的には, 対象不動 産のキャピタルゲインとインカムゲインである。 オリンピックにより, 直接的あるいは間接的に影 響があり，売上などの収益性が継続的に向上した り，買主の購買意欲の高まりなどにより，キャッ プレートが低下すれば，取引価格が上昇すること となるであろう。

なお, 日本不動産研究所は, わが国の過去の才 リンピック開催地 (東京, 札幌及び長野) の地価 の動きについて,「全国的な趨勢を逸脱した地価 の動向は見られず，地価は一時のイベントよりも， 全般的な社会・経済情勢をより色濃く反映するも のと考えられる」と分析している10。

\section{（８）J-REIT市場}

J-REIT（不動産投資信託）は，株式と不動産の 両方の特徵を併せ持つハイブリット型の投資商品 である。オリンピックの経済効果により企業業績 が向上すると，平均株価にも影響し，上場株式と してのJ-REITもその恩恵を受けるであろう。な お, J-REITが保有している不動産の約 6 割が東 京に所在しており, 保有不動産がオリンピックに 関連して, 収益が向上すれば, 不動産キャッシュ フロー面でもプラスの効果が発生し, 配当が増大 するであろう。また, 保有不動産の価格上昇は,
NAV（Net Asset Value）の上昇を通じて，株価 を押し上げるきっかけになるであろう。

\section{7. まとめ}

2020年東京オリンピック開催決定は, アベノミ クスで徐々に上向きになってきた日本経済に明る いニュースとなった。実際の開催は 6 年後であ り, 今後, 大会に向けて, 競技施設の新設やイン フラ整備が始まるであろうが, 震災復興, 全国レ ベルのインフラ老朽化問題, 東京での新規大型マ ンション，オフィスビルの建設など，建設工事の ニーズが集中しており, 建設労働力の不足が深刻 化してきている。

本稿は, オリンピックの不動産市場に与える経 済効果を金額で予測するのではなく，そのメカニ ズムを解明した。具体的には, 用途によりそのイ ンパクトも異なることから，用途別に考察した。 オリンピックを合計30日間のスポーツの祭典と捉 えれば，不動産市場での影響はかなり限定的と言 えるが，様々な業種へのインパクトがあり，また， 日本, 特に東京のPRにもなるので, その効果が 持続的に発揮されれば，海外からの注目が高まり， 不動産市場にも相当程度のプラスの効果が期待で きるであろう。今後は，オリンピックへ向けた準 備の進渉状況とファンダメンタルズの状況, そし て不動産市場への影響を注意深く見ていく必要が あろう。

2020年オリンピックは, それに向けて日本の首 都，東京をより快適で安全で質の高い都市とし， 国際的にも競争力の高いものに再構築する, いい きっかけになると信じている。大会の成功と日本, 東京の発展を祈りたい。

\section{参考文献}

1 ） 久ずほ総合研究所「2020年東京オリンピックの経済 効果」(2013年 9 月27日)

2 ）森記念財団 都市戦略研究所「2020年東京オリンピッ ク・パラリンピック開催に伴うわが国への経済波及 
効果」(2014年 1 月)

3 ） ニッセイアセットマネジメント「東京オリンピック 開催とJ-REIT市場」(2013年 9 月 9 日)

4) ジョーンズ・ラング・ラサール「東京オリンピック : ホテルマーケットへのインパクト」(2013年11月 6 日)

5 ）大竹文雄・日本経済研究センター「オリンピックの 意外な経済効果」(2013年10月29日)

6 ) “五輪で利益を得る 8 大産業”「人民網日本語版」(2008 年 6 月 10 日)

7 ) Eleazar D. Melendez「オリンピック開催は儲かるの か?」The Huffington Post (2013年 9 月 5 日)

8 ) 吉野薰「2014年の不動産市場」(一財) 日本不動産研 究所「不動産調查 No.392」(2014年 1 月31日)

9 ）東京商エリサーチ「2020年東京オリンピック開催・ 経営者アンケート」2013年10月実施, 回答者数3,131 名 (企業数：3,096社)

10）小林庸至・野村総研「2020年の東京オリンピックを 契機とした東京再構築の必要性」NRIパブリックマネ ジメントレビュー Nov. 2013 vol.124
11）川名剛・大和総研「オリンピック・レガシーの概念」 重点テーマレポート（2014年 1 月30日）

12）竹内一雅・ニッセイ基礎研「外国人の国内宿泊動向」 基礎研レポート（2014年 1 月20日）

13）横山愛ほか「オリンピックの経済効果」第32回法政 大学懸賞論文優秀論文集（2009年度）

14) Rose, A. K. and Spiegel, M. M. (2009), “The Olympic Effect”, NBER Working Paper Series

15) Susan Simmons, "Analysis of the 1996 Summer Olympic Games on Real Estate Markets in Atlanta”, Master Thesis of Massachusetts Institute of Technology (2010)

16) Kari A. Oshanski, "The Impact of Olympics on Public Open Space in Host Cities”, Master Thesis of Ohio State University (2013)

17) Ernst-Jan van Prooye, “2028 Real estate development strategies towards a successful Olympic legacy," Master Thesis of Delft University of Technology (2010) 